\section{$\underset{\substack{\text { hommes } \\ \text { \& migrations }}}{ }$}

\section{Hommes \& migrations}

Revue française de référence sur les dynamiques

migratoires

$1313 \mid 2016$

1983, le tournant médiatique

\title{
Des écrans blancs aux stigmates racistes
}

\section{Marie Poinsot}

\section{(2) OpenEdition \\ Journals}

Édition électronique

URL : http://journals.openedition.org/hommesmigrations/3549

DOI : 10.4000/hommesmigrations.3549

ISSN : 2262-3353

Éditeur

Musée national de l'histoire de l'immigration

Édition imprimée

Date de publication : 1 janvier 2016

Pagination : 1

ISBN : 978-2-919040-34-6

ISSN : $1142-852 X$

\section{Référence électronique}

Marie Poinsot, «Des écrans blancs aux stigmates racistes », Hommes \& migrations [En ligne], 1313

2016, mis en ligne le 17 juin 2016, consulté le 24 septembre 2020. URL : http://

journals.openedition.org/hommesmigrations/3549; DOI : https://doi.org/10.4000/

hommesmigrations.3549 


\section{DES ÉCRANS BLANCS AUX STIGMATES RACISTES}

par MARIE POINSOT, rédactrice en chef.

En ce début d'année 2016, la revue Hommes \& Migrations s'intéresse à un maillon faible des études migratoires. En croisant l'histoire de l'immigration et celle des médias, le dossier coordonné par Yvan Gastaut explore la manière dont les écrans (cinéma, télévision, Internet) ont façonné les représentations médiatiques de l'immigration en France. Ce dossier remonte aux sources de la fabrication du discours médiatique sur l'immigration depuis les années qui ont suivi la guerre d’Algérie. Il analyse comment les stéréotypes initiaux de l'" Arabe " vont imprégner l'imaginaire social en une multitude d'images sur les populations originaires du Maghreb. Sous forme de révolution silencieuse, les médias colonisent progressivement les mentalités en imposant des figures de l'immigré et de ses enfants dont l'impact va être durable dans la société française. En l'espace de deux décennies, on passe des écrans blancs (en référence aux « écrans pâles ", titre d'un colloque organisé par le CSA en 2004) où les travailleurs immigrés sont invisibles sur le sol hexagonal en tant que sujets légitimes, à une stigmatisation des jeunes des banlieues à peine «naturalisés » dans la société, mais déjà placés sous haute surveillance.

L'année 1983 marque un tournant majeur dans la prise en compte des populations immigrées dans les médias sous la pression d'une actualité chargée : les actes racistes se multiplient dans un contexte de crise sociale et économique qui s'affirme par un changement de cap du gouvernement socialiste et par la montée du Front national. C'est aussi l'année où la seconde génération de l'immigration se mobilise à travers la Marche pour l'égalité et contre le racisme relayée par les médias qui en assurent une soudaine et peut-être éphémère visibilité. C'est encore l'année où les performances artistiques et sportives de certains jeunes immigrés les propulsent dans la lumière, leur conférant le statut de nouvelles figures populaires.

En partant d'un des événements ou des faits divers qui marquent l'année 1983, afin d'éclairer les signifiants stéréotypés qui se construisent, chaque article décompose les images que les médias en rapportent. Ceux-ci s'organisent autour de deux pôles contraires mais connectés : un pôle " sécuritaire " regroupe les images de grèves, d'émeutes, de banlieues et de crimes racistes avec, en toile de fond, la menace du Front national et les bavures policières ; un pôle "multiculturel » rassemble des actions collectives, des personnalités, des émergences culturelles qui composent désormais la créativité française. Depuis les années 1980, ces discours médiatiques entament un bras de fer dans la conquête de l'opinion française, jusqu'à ce que la tendance sécuritaire finisse par prendre le dessus. Longtemps marginalisé dans les médias, le racisme devient le mot d'ordre des représentations de l'immigration.

Les photos qui illustrent ce dossier sont issues du fonds d'archives de l'agence IM'média, créée dans les années 1980 par des journalistes qui voulaient montrer d'autres visages de l'immigration que ceux habituellement véhiculés par les médias. La revue tient à remercier chaleureusement Mogniss Abdallah pour sa collaboration irremplaçable.

Dans le cadre de la semaine d'éducation et d'actions contre le racisme et l'antisémitisme, Hommes \& Migrations a voulu contribuer à la programmation du Musée national de l'histoire de l'immigration en proposant des ressources pour la réflexion sur la portée de cet héritage des années 1980 en matière de racisme et en interrogeant ceux qui agissent dans ce domaine. 